\title{
SUSTAINABLE BIRD CREATION SYSTEM IN THE QUILOMBOLA COMMUNITY OF DOURADOS, MATO GROSSO DO SUL
}

Sistema Sustentável De Criação De Aves Na Comunidade Quilombola De Dourados, Mato Grosso Do Sul

DOI: 10.30612/re-ufgd.v6i11.8918

Sandra Verza da Silva*, $2^{1}$

Euclides Reuter de Oliveira3

Vladson Carbonar2

Marisa de Fátima Lomba de Farias4

Thaís Lemos Pereira5

Andrea Maria de Araújo Gabriel3

Elaine Barbosa Muniz6

Jefferson Rodrigues Gandra3

Érika Rosendo de Sena Gandra7

Nara de Medeiros Pordeus 5

Recebido em: 10/10/2018

Aceito em: 24/05/2019

Abstract: Sustainable poultry farming has been gaining more and more expressiveness in the market. This increase in demand for semicaipira poultry is due to the appreciation of products that are generated taking into account the care of the environment and human and animal welfare. The purpose of this extension work was to promote and monitor the production of semicaipira chickens, which is in the transition phase, from a traditional system for an organic system in the Quilombola Community Dezidério Felipe de Oliveira, located in Picadinha, Dourados, MS. The development of this activity was based on the principles of sustainability and the concern to value the work of the

11Trabalho apoiado pela PROEX/UFGD (Pró-Reitoria de Extensão e Cultura); CNPq (Conselho Nacional de Desenvolvimento Científico e Tecnológico), Centro Vocacional Tecnológico em Agroecologia e Produção Orgânica, em Mato Grosso do Sul e ao Núcleo de Agroecologia e Produção Orgânica em Sistema Vegetal e Animal.; 2Bolsista de Extensão - CNPq (vladsoncarbonari@gmail.com); 3Docentes da UFGD, Faculdade de Ciências Agrarias, Dourados, MS (euclidesoliveira@ufgd.edu.br); 4Docente do curso de História, Faculdade de Ciências Humanas (FCH) da UFGD, Dourados, MS (marisalomba@ufgd.edu.br); 5Mestrandos do Curso de Zootecnia/UFGD (thais-lemos01@hotmail.com); 6Docente da UNIOSTE, Marechal Cândido Rondon, PR (ebmuniz@yahoo.com.br); 6Discentes do curso de Zootecnia/UFGD; 7Bolsista de Pós-doutorado (PNPD-Capes)/UFGD (erica.sena@gmail.com); *Autor correspondente: sandraverza@yahoo.com

Verza et al, p. 130 a 139 
community, maintaining its traditional way of life. The practices were developed from November 2017 to September 2018, with the follow-up of two production cycles. The birds were raised with corn, concentrated ration and vegetables produced in organic system. The practice of sustainable bird management brought together the scientific knowledge acquired by the UFGD teachers and students and the accumulated experiences of Quilombolas with the animal production system. The results showed an increase in income, with sales of $72 \%$ of the poultry purchased in the first cycle, and an improvement in the breeding method of the second cycle, which resulted in greater weight gain in broilers. In addition, with the strengthening and sustainable development of poultry production in the Quilombola community, an improvement in the food quality of the families involved in the project was observed.

Key words: Aviculture, Quilombos, semicaipira chickens, sustainability, university extension.

Resumo: A avicultura sustentável vem ganhando cada vez mais expressividade no mercado. Esse aumento na procura pelo modo de criação de aves semicaipiras se deve a valorização de produtos que são gerados levando em consideração os cuidados com o meio ambiente e com o bem-estar humano e animal. Objetivou-se por meio deste trabalho de extensão promover e acompanhar a produção de aves semicaipiras, que se encontra em fase de transição, de um sistema tradicional para uma criação em sistema orgânico, na Comunidade Quilombola Dezidério Felipe de Oliveira, localizada na Picadinha, município de Dourados, MS. O desenvolvimento desta atividade teve como base os princípios de sustentabilidade e a preocupação em valorizar o trabalho da comunidade, mantendo seu modo de vida tradicional. As práticas foram desenvolvidas no período de novembro de 2017 a setembro de 2018, com o acompanhamento de dois ciclos de produção. As aves foram criadas com milho, ração concentrada e hortaliças produzidas em sistema orgânico. A prática de manejo sustentável de aves reuniu os saberes científicos adquiridos pelos docentes e discentes da UFGD e as experiências acumuladas dos Quilombolas com o sistema de produção animal. Os resultados mostraram um aumento na renda, com venda de $72 \%$ das aves adquiridas no primeiro ciclo, e uma melhora no modo de criação das aves do segundo ciclo que proporcionou maior ganho de peso nos frangos de corte. Além disso, com o fortalecimento e desenvolvimento sustentável da produção de aves na comunidade Quilombola, constatou-se uma melhoria na qualidade alimentar das famílias envolvidas no projeto.

Palavras-chave: Avicultura, frangos semicaipiras, extensão universitária, Quilombos, sustentabilidade.

\section{Introduction}

The preference for healthy products has been increasingly recurrent among consumers due to the demands of a more attentive consumer market with regard to the origin of food and the conditions under which slaughtered animals are reared (GESSULI, 1999; VERCOE et al., 2000). The growing demand for food from agroecological production systems and free from toxic residues, implemented from alternative activities is a worldwide trend that is also observed in Brazil (VERBEKE and VIANE, 2000; OLIVEIRA et al., 2012). And the sustainable creation of birds takes into account this issue of welfare of the animals destined for consumption and of the 
people who provide care and maintenance of these animals (VERBEKE and VIANE, 2000; BLOKHUIS et al., 2000; ARENALES et al., 2008, FURLAN et al., 2018).

According to Machado (1998), the information of alternative models of animal and vegetal production allow, in addition to the gains with the production, the unrestricted protection of the producer and the conservation of the environment. The importance of family farming on small farms is fundamental for the improvement of the quality of life of the population, since in these is produced a large part of the products that compose the basic basket of workers, besides increasing the source of income by selling the surplus. As, for example, we have the case of the community Quilombola Dezidério Felipe de Oliveira, located in Mato Grosso do Sul, involved in extension actions, which is characterized as a small family property, that is, develops family agriculture.

The raising of chicken for slaughter is an activity in which many rural producers invest to diversify and to bill a little more with agribusiness. Chicken farm is one of the options, but it is out of the reality for many people, because the assembly of a shed with all the infrastructure required for the development of the birds is expensive. On the other hand, the small producer can raise semicaipira chickens in a less expensive system with a short-term return on the low capital employed. This lineage of bird, created in the field that lies between the farm chicken and the pure caipira, also receives other denominations: pasture chicken, semi-confined, semi-intensive or natural. In compensation, the producer ends up winning twice as much as the farm chicken. As this type of raising does not require high investment, the activity is considered an excellent economic alternative for small farmers.

Although semicaipira subclassification may make it difficult for the consumer to differentiate between this product and the traditional caipira (VERCOE et al., 2000; TEIXEIRA, 2017), the semicaipira for having the meat with flavor and texture similar to the most rustic example, has good acceptance in the consumer market. The traditional caipira chicken takes on average 4 to 6 months to reach slaughter weight, the 'semi', from 45 to 90 days. The main difference is in the feed used during the first month of life, which boosts its development and allows early slaughter. The basis of food is made from corn and vegetable residues (SANTOS et al., 2005). Therefore, the creation of semicaipiras birds is an interesting alternative source of income for the Quilombola community in question.

Thinking about this, the Federal University of Grande Dourados, which has been developing actions aimed at strengthening animal and vegetable production, has attempted to value the way of life and traditional habits of such a community. The people of this community involved 
in the extension actions developed, are remnants of quilombos, that means that they maintained a differentiated identity, linked to the land as territory of life and work. Therefore, the conception of land, freedom, life and work remains in the memory of this group (OLIVEIRA et al., 2012).

Based on the points made above, the purpose of this work was to encourage, promote, and follow the changes in the structure of poultry production, which is in the transition phase. Thus, this activity based on sustainability fundamentals aimed at improving food quality and increasing revenue and income generation, as well as improving the product, adding value to it and creating conditions for the permanence of families in the Quilombola community.

\section{Materials and Methods}

The semicaipira chicken production system started in the Quilombola Dezidério Felipe de Oliveira Community, located in Picadinha, Dourados, MS, in 2009. Initially, through a project via CNPq / UFGD, a group of 8 families were contemplated with 50 chicks and ration from the initial phase, growth and termination, that comprised a total of 90 days of creation. The University offered theoretical and practical courses, lectures and practical orientations addressing the management and creation of birds, financed through extension projects. The families were then instructed to market the surplus birds and, with the money obtained, to acquire another batch of chicks and feed and to continue this action over time.

The present work was carried out from December 2017 to September 2018, aiming to analyze the transition in the structure of the production of a system of traditional poultry farming for a sustainable system. To this end, two production cycles of semicaipira birds were followed, with the creation of 50 chicks in each, one started in December 2017 and the other in June 2018.

The community bought with its own resources 8 bags of concentrated feed and 8 bags of $60 \mathrm{~kg}$ of corn, which were divided for each cycle. The birds were also fed on organically grown residues of vegetables. To verify fattening, 20 broiler chickens in cut-off point from each cycle were weighed at random (Figure 1). 
suggestions. The evaluations by the community were based on the ability to reproduce the information received.

\section{Results and Discussion}

In the first cycle, of the 50 birds purchased by the Quilombola Community, 4 died, 10 chickens were selected for their own consumption, divided among the 8 families that make up the producer group, and the rest of the birds were sold. Of these, were sold 26 clean chickens and 10 chickens with feather. Expenses and profits were recorded, which allowed the purchase of a new lot (second cycle) for breeding, a canvas was bought to make a fence around the chicken coop and an enclosed place was built to store the feed.

In the second cycle 5 chickens died, were sold 25 chickens clean and 10 with feather, and the other 10 chickens were distributed among the families. Part of the income will be invested to obtain another batch of chicks and concentrate for breeding until slaughter, repairs to the facilities and distributed among the participants. The ecological agriculture, and in it the production for domestic consumption, is an exercise of total quality in agriculture, oriented to the full and intelligent use of the resources available in the property (KHATOUNIAN, 2001).

Few birds died, a fact that is important to characterize the real problems in the activity, especially the difficulties faced in transporting the chicks to the place of breeding, a fact that may have contributed to the death of these animals in the initial phase. Table 1 shows the production of chickens / cycle and the average weight of feathered chickens.

Table 1. Quantity and average weight of birds per production cycle.

\section{Production Chickens (n) Mean weight of males (kg) Mean weight of females (kg)}

$\begin{array}{lccc}\text { First cycle } & 46 & 3.500 & 3.000 \\ \text { Second cycle } & 45 & 3.700 & 3.500\end{array}$

The weight of males at cut-off point in the first cycle, as can be seen in Table 1, was around $3.5 \mathrm{~kg}$, and females was approximately $3.0 \mathrm{~kg}$. Mean males weight in the second cycle was $3.7 \mathrm{~kg}$ and females $3.5 \mathrm{~kg}$. This difference in weights may be related to the breeding season (rainier period), since the origin of the animals were from the same source of production, it is noted that environmental conditions can influence the production and behavior of birds (SILVA and SILVA, 
1998). It is observed that the production of the second cycle obtained average weight, for both males and females, higher than the production of the birds of the first cycle. This increase in weight can be seen in Figure 2, where half the heavy birds weigh more than $2.5 \mathrm{~kg}$.

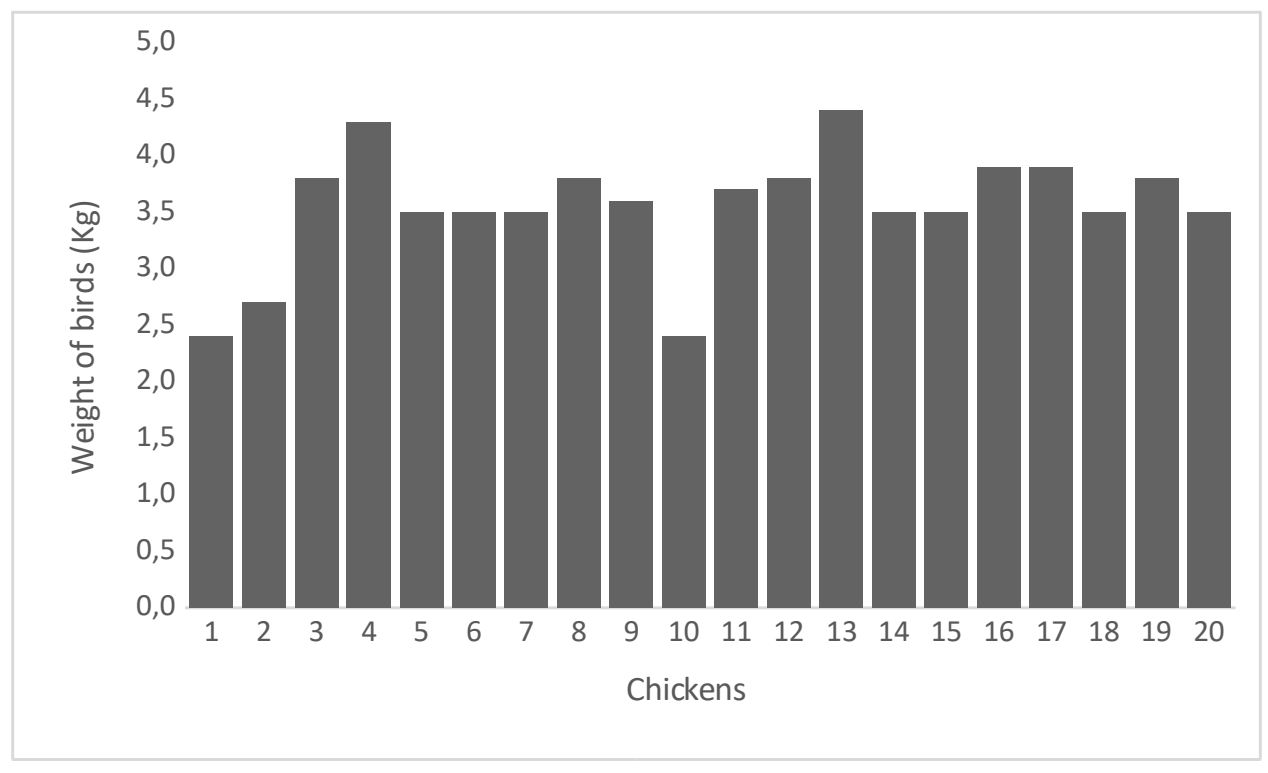

Figure 2. Weight of the chickens at slaughter point of the second production cycle.

Another justification for this difference in weights among lots may also be due to the improvements that were made in the chicken coop with the income obtained in the first cycle. It is worth mentioning here that the chicken coop was built in an airy place, with perches, drinking fountains and feeders positioned at a suitable height (Figure 3), and water always clean, fresh and at will, which passes through a water wheel until it reaches in a water tank that distributes it to the production areas. It is recommended that in every breeding system, natural resources should be respected and its objective is to become self-sustaining, aiming at preserving the biodiversity of ecosystems (ARENALES et al., 2008). 
becomes key for the participants of sustainable family agriculture to reach the consumer. These strategies, according to the logic of consumption-oriented production, must determine the direction of the production of goods or services for the consumer.

There was an improvement in the quality of life, due to the greater diversity of food for consumption, and in the income generation of the group of people involved. The problems that arose during the development of the activity brought as a benefit experience and union between the participants in the whole process, which was significant for the success in the creation of semicaipiras birds.

\section{Conclusion}

During the activities was observed the improvement in the production of birds, the increase in income generation, the improvement of food quality and the enhancement of production knowledge by Quilombola families. In addition, with the knowledge transmitted by extension project collaborators and the commitment of the producers of the Quilombola community, alternatives were created to strengthen family agriculture and to create a more sustainable and social productive organization.

\section{References}

ARENALES, M.D.C.; ROSSI, F.; FERREIRA, R.G.S.; FERREIRA, D.G.S. Criação orgânica de frangos de corte e aves de postura. Editora Aprenda fácil. Viçosa, MG, 2008.

BLOKHUIS, H.J.; EKKEL, E.D.; KORTE, S.M. HOSPER, H.; VAN REENEN, C.G. Farm animal welfare research in interaction with society. Veterinary Quality, v. 22, p. 217-222, 2000.

FURLAN, R.L.; MACARI, M.; MATEUS, J.R. Bem estar das aves e sua implicações sobre o desenvolvimento e produção. Disponível em: Acesso em 07/10/2018.

GESSULI, O.P. Avicultura alternativa sistema "ecologicamente correto" que busca o bemestar animal e a qualidade do produto final. Porto Feliz: OPG, 1999, 217 p.

KHATOUNIAN, C.A. A Reconstrução Ecológica da Agricultura. Botucatu, ISBN 85-88581-264, 345 p, 2001.

LAGO, A.; LENGLER, L.; CORONEL, D.A.; SILVA, T.N. Agricultura familiar de produtos orgânicos: Um olhar sob a ótica do marketing. Revista Extensão Rural, n.13, p. 93-116, 2006.

MACHADO, A.M.B. Educação ambiental para o desenvolvimento sustentável em assentamentos rurais: contribuições de um estudo de representações sociais. Cadernos de Ciência \& Tecnologia, 
